\title{
PEMBERIAN TEMPE MENURUNKAN KADAR MALONDIALDEHYDE (MDA) DAN MENINGKATKAN AKTIVITAS ENZIM SUPEROXIDE DISMUTASE (SOD) PADA TIKUS DENGAN AKTIVITAS FISIK TINGGI
}

\section{(The tempe giving decrease malondialdehyde $[M D A]$ level and increase the activities of superoxide dismutase enzyme $[S O D]$ on rats with high physical activities)}

\author{
Iriyanti Harun ${ }^{1 *}$, Hardhono Susanto ${ }^{2}$, Ali Rosidi ${ }^{3}$ \\ ${ }^{1}$ Magister Ilmu Gizi, Fakultas Kedokteran, Universitas Diponegoro, Semarang 50275 \\ ${ }^{2}$ Bagian Patologi Anatomi, Fakultas Kedokteran, Universitas Diponegoro, Semarang 50275 \\ ${ }^{3}$ Program Studi Ilmu Gizi, Universitas Muhammadiyah, Semarang 50273
}

\begin{abstract}
The aim of this research was to analyze the influence of tempe giving to the oxidative stress in rats with high physical activities. This research was true experimental post-test only with control group design on 35 rats. The rats were given high physical activities and tempe treatments for 30 days. Those rats were divided into 5 group, which were: control 1 without giving tempe and supplement, control 2 with the giving of the commercial supplement, treatment 1 with giving $0.75 \mathrm{~g}$ tempe/200 $\mathrm{g}$ of body weight/day, treatment 2 with giving $1.5 \mathrm{~g}$ tempe/200 g of body weight/day and treatment 3 with giving $3 \mathrm{~g}$ tempe/200 $g$ of body weight/day. At the end of this research, it was done the examination of the plasma MDA level by using TBARS method and activities of SOD enzyme using spectrofometry. The statistical analysis used One-way ANOVA Tests and Post Hoc LSD. The result showed that the tempe giving at various doses was significantly influenced to the reduction of MDA level $(p<0.05)$ and also significantly influenced to the increasing activities of SOD enzyme $(p<0.05)$. The giving of $3 \mathrm{~g}$ tempe was the most effective dose to the reduction of MDA level and the increasing activities of SOD enzyme. The conclusion was tempe could decrease the MDA level and increase the activities of SOD enzyme significantly in oxidative stress rats with high physical activities.
\end{abstract}

Keywords: antioxidant, high activities, $M D A$, oxidative stress, SOD, tempe

\section{ABSTRAK}

Tujuan penelitian ini adalah untuk menganalisis pengaruh pemberian tempe terhadap stres oksidatif pada tikus dengan aktivitas fisik tinggi. Penelitian ini merupakan penelitian true experimental, post test only with control grup design pada 35 ekor tikus yang diberi aktivitas fisik tinggi dan perlakuan pemberian tempe selama 30 hari. Tikus dibagi menjadi 5 perlakuan yaitu kontrol 1 (tanpa pemberian tempe dan suplemen), kontrol 2 (pemberian suplemen komersial), perlakuan 1 (pemberian tempe 0,75 $\mathrm{g} / 200 \mathrm{~g} \mathrm{bb} / \mathrm{hari}$ ), perlakuan 2 (pemberian tempe $1,5 \mathrm{~g} / 200 \mathrm{~g} \mathrm{bb} / \mathrm{hari}$ ) dan perlakuan 3 (pemberian tempe $3 \mathrm{~g} / 200 \mathrm{~g}$ bb/hari). Pada akhir penelitian dilakukan pemeriksaan menggunakan kadar MDA plasma dengan TBARS dan kadar SOD. Analisis statistik dilakukan uji one way anova dan post hoc LSD. Hasil menunjukkan bahwa pemberian tempe berbagai dosis berpengaruh signifikan terhadap penurunan kadar MDA $(p<0,05)$ dan juga berpengaruh signifikan terhadap peningkatan aktivitas enzim SOD $(p<0,05)$. Pemberian tempe $3 \mathrm{~g} / 200 \mathrm{~g}$ bb merupakan dosis efektif terhadap penurunan kadar MDA dan peningkatan aktivitas enzim SOD. Kesimpulannya tempe dapat menurunkan kadar MDA dan meningkatkan aktivitas enzim SOD secara signifikan pada tikus stres oksidatif dengan aktivitas fisik tinggi.

Kata kunci: aktivitas tinggi, antioksidan, MDA, SOD, stres oksidatif, tempe

\section{PENDAHULUAN}

Stres oksidatif merupakan suatu kondisi ketidakseimbangan antara produksi radikal bebas dengan antioksidan di dalam tubuh sehingga akan memicu kondisi patologis seperti penuaan, inflamasi, penyakit kardiovaskular, neurodegeneratif dan kanker. Keterkaitan antara latihan fisik dan stres oksidatif sangat tergantung pada intensitas dan durasinya (Yavari et al. 2015). Atlet profesional sering kali melakukan latihan fisik melebihi yang dianjurkan, apalagi saat menghadapi kompetisi, dalam jangka panjang intensitas latihan yang meningkat ini tentunya sangat merugikan dan dapat menimbulkan efek negatif salah satunya yaitu meningkatnya senyawa oksidan

$\overline{\text { "Korespondensi: Telp: }}+628114190183$, Surel: iriyanti.magi2015@gmail.com 
dalam tubuh. Apabila sistem pertahanan antioksidan tidak mampu menetralisir senyawa oksidan, maka akan memicu kondisi stres oksidatif (Pingitore et al. 2015; Yavari et al. 2015).

Berolahraga berat akan menghasilkan $R e$ active Oxygen Species (ROS) yang berlebih sehingga menurunkan pertahanan antioksidan dalam tubuh dan hasilnya adalah stres oksidatif. Untuk meminimalisir efek tersebut suplemen multivitamin sintetik digunakan, karena dianggap dapat meningkatkan kapasitas fisik serta memberikan keunggulan yang kompetitif khususnya bagi atlit (Williams 2004). Penelitian yang dilakukan di Birmingham membuktikan bahwa berolahraga berlari sejauh 142 mil dapat menyebabkan stres oksidatif yang mampu bertahan hingga satu bulan (Turner et al 2011).

Salah satu Biomarker yang paling umum digunakan untuk mengukur derajat stres oksidatif adalah Malondialdehyde (MDA) yang merupakan hasil akhir dari peroksidasi lipid (Moselhy et al. 2013). Meningkatnya pembentukan radikal bebas dalam tubuh dimulai pada saat 12-24 jam setelah aktivitas fisik, selanjutnya akan meningkat setelah 48-72 jam dan akan kembali normal setelah 72 jam sesuai intensitas dan lamanya aktivitas fisik (Kiyatno 2009).

Secara alami tubuh mempunyai kemampuan untuk menangkal radikal bebas dengan membentuk antioksidan endogen yang dihasilkan oleh tubuh yang kadarnya dapat diukur melalui GPx (Glutation Peroxidase), katalase dan aktivitas enzim Superoxide Dismutase (SOD). Aktivitas fisik yang terlalu tinggi akan mengakibatkan kadar radikal bebas dalam tubuh juga meningkat sehingga antioksidan endogen tidak mampu untuk menetralisir radikal bebas, dibutuhkan antioksidan eksogen dalam jumlah yang lebih banyak untuk menetralisir efek radikal bebas (Astuti 2008). Enzim SOD merupakan pertahanan pertama terhadap proses peroksidasi lipid yang berlebihan di dalam tubuh dan aktivitasnya bergantung pada logam mineral mangan (Mn), Zink (Zn) dan tembaga $(\mathrm{Cu})$ agar dapat bekerja dengan optimal (Powers \& Jackson 2010). Tempe memiliki kelebihan yaitu mempunyai ketersediaan mineral lebih baik dibandingkan kedelai (Astawan et al. 2016).

Tempe merupakan salah satu produk olahan dari kedelai hasil fermentasi ragi rhizopus spp yang tinggi antioksidan alami, tempe mempunyai komponen senyawa bioaktif isoflavon yang berperan sebagai antioksidan eksogen di dalam tubuh sehingga dapat mencegah terjadinya kerusakan sel oleh radikal bebas (Utari \& Riyadi 2010). Beberapa penelitian terkait dengan antioksidan menunjukkan bahwa suplementasi kedelai dapat meningkatkan antioksidan dan mencegah terjadinya peroksidasi lipid (Yoon \& Park
2014). Aktivitas enzim SOD pada proses fermentasi tempe terjadi bersamaan dengan pertumbuhan jamur, dimulai sejak 24 jam dan selanjutnya meningkat sampai 60 jam fermentasi dan kemudian mulai menurun karena pertumbuhan jamur dipengaruhi oleh kondisi lingkungan (Astuti et al. 2000). Pemilihan tempe sebagai sampel dalam penelitian ini karena tempe mengandung zat bioaktif isoflavon tertinggi dibandingkan produk fermentasi kedelai lainnya yaitu sebanyak 60,61 mg dan pada tempe dengan proses pemasakan jumlah isoflavon sebesar 35,64 $\mathrm{mg}$ (Bhagwat et al. 2008).

Beberapa penelitian telah membuktikan manfaat mengonsumsi tempe seperti pada penelitian Desminarti \& Anwar (2012) menunjukkan bahwa pemberian bubuk instan tempe sebanyak $35 \%$ pada tikus hiperglikemia memberikan pengaruh yang paling kuat dalam menurunkan kadar MDA serum sebanyak $18,75 \%$. Utari (2011) dalam penelitiannya juga menunjukkan bahwa konsumsi tempe dapat meningkatkan aktivitas enzim SOD sebesar $56,9 \%$ dan menurunkan kadar MDA sebesar $10,4 \%$ pada wanita menopause Hasil penelitian di korea juga membuktikan bahwa suplementasi isoflavon dapat meningkatkan aktivitas enzim SOD, GSH-px dan menurunkan kadar MDA pada tikus (Yoon \& Park 2014).

Penelitian ini bertujuan untuk mengetahui pengaruh pemberian tempe terhadap kadar MDA dan aktivitas enzim SOD pada tikus wistar dengan aktivitas fisik tinggi. Penelitian ini diharapkan dapat memberikan informasi yang bermanfaat bagi ilmu pengetahuan dan juga dapat meningkatkan pengetahuan bagi masyarakat bahwa tempe dapat digunakan sebagai alternatif makanan fungsional sebagai sumber antioksidan alami yang aman bagi tubuh sehingga dapat meminimalisir terjadinya stres oksidatif yang diakibatkan oleh aktivitas tinggi.

\section{METODE}

\section{Desain, tempat, dan waktu}

Penelitian ini merupakan penelitian true experiment, post test only control group design. Penelitian ini dilakukan di Laboratorium Pusat Studi Pangan dan Gizi (PAU) Universitas Gadjah Mada Yogyakarta. Penelitian dilakukan dalam rentang waktu bulan Januari - Februari 2017.

\section{Jenis dan cara pengambilan sampel}

Sampel dalam penelitian ini menggunakan tikus putih jantan jenis wistar yang diperoleh dari Laboratorium Pusat Studi Pangan dan Gizi (PAU) Universitas Gadjah Mada Yogyakarta dengan usia $2-3$ bulan dan berat badan $\pm 200 \mathrm{~g}$. Besar sampel dalam penelitian ini sebanyak 35 ekor tikus yang 
dibagi dalam 5 perlakuan yaitu 2 kontrol dan 3 perlakuan. Peralatan yang digunakan berupa kandang, wadah pakan, wadah minum, waterbath untuk latihan renang tikus dengan kedalaman $50 \mathrm{~cm}$, timbangan digital, spuit sonde, dan alat pemeriksaan kadar MDA dan SOD. Bahan pakan tikus Comfeed AD II diperoleh dari Laboratorium Pusat Studi Pangan dan Gizi (PAU) dengan komposisi kadar air $12 \%$, protein kasar $15 \%$, lemak kasar 3-7\%, serat kasar 6\%, abu 7\%, kalsium 0,9$1,1 \%$, dan fosfor $0,6-0,9 \%$. Tempe diperoleh dari pasar lokal kota Yogyakarta, multivitamin yang diberikan merk komersial dengan komposisi antioksidan vitamin A 1000IU, vitamin C $150 \mathrm{mg}$, vitamin E $15 \mathrm{mg}$, zinc oxide $15 \mathrm{mg}$, vitamin $\mathrm{B}$ kompleks dan mineral serta reagen MDA dan SOD.

\section{Tahapan penelitian}

Tikus sebanyak 35 ekor diadaptasi selama 3 hari dan diberikan pakan standar comfeed AD II dan aquadest ad libithum, selanjutnya dilakukan penimbangan berat badan tikus. Sebelum aktivitas fisik dan diberi perlakuan, dilakukan pengambilan darah di bagian mata (plexus retro orbitalis) untuk standarisasi kadar normal MDA plasma dan SOD tikus yang dianggap sehat. Tahap selanjutnya sebelum intervensi, dilakukan renang pendahuluan dengan tujuan untuk mengetahui waktu aktivitas fisik maksimal tikus yang dipakai sebagai dasar lama waktu pelatihan renang, sehingga berdasarkan renang pendahuluan didapatkan waktu renang sekitar \pm 40 menit.

Tikus diberi aktivitas fisik tinggi selama 30 hari sebagai induksi stres oksidatif yang dibagi dalam 5 perlakuan, yaitu K1 tanpa pemberian suplemen multivitamin dan perlakuan, K2 diberikan suplemen multivitamin merk komersial dengan dosis $15 \mathrm{mg}$ dihomogenkan dengan aquades menjadi $4 \mathrm{ml}$ dan diberikan dengan sonde lambung, P1 diberi tempe sudah melalui proses steam blanching (pengukusan) selama 5 menit sebanyak $0,75 \mathrm{~g} / 200 \mathrm{~g}$ bb tikus, $\mathrm{P} 2$ diberi tempe dengan dosis $1,5 \mathrm{~g} / 200 \mathrm{~g}$ bb tikus dan P3 diberi tempe dengan dosis $3 \mathrm{~g} / 200 \mathrm{~g}$ bb tikus, masingmasingnya dihomogenkan (diblender) dengan aquades menjadi $4 \mathrm{ml}$ dengan metode sonde lam- bung dan diberikan sehari sekali pada pagi hari setelah aktivitas fisik tinggi.

Penimbangan berat badan dilakukan kembali pada akhir penelitian, selanjutnya dilakukan pengambilan darah melalui plexus retro orbitalis dimana hasil analisis dalam penelitian ini adalah kadar MDA TBARS dan aktivitas enzim SOD dengan metode spektrofotometri.

\section{Pengolahan dan analisis data}

Data yang diperoleh disusun dalam bentuk master tabel, selanjutnya dilakukan analisis statistik dengan menguji normalitas menggunakan Shapiro Wilk karena jumlah sampel $<50$. Data yang berdistribusi normal dianalisis dengan uji One Way Anova dilanjutkan dengan Post Hoc $L S D$, apabila tidak berdistribusi normal maka digunakan uji Kruskal Wallis dilanjutkan dengan Mann Whitney. Dilakukan uji Spearman untuk mengetahui korelasi antara kadar MDA dan aktivitas enzim SOD.

\section{HASIL DAN PEMBAHASAN}

\section{Karakteristik hewan coba}

Berat badan (g). Rata-rata berat badan tikus selama penelitian dapat dilihat pada Tabel 1. Penimbangan berat badan bertujuan untuk memantau perubahan berat badan tikus selama penelitian, ini terkait dengan aktivitas fisik tinggi, pemberian pakan standar dan pemberian dosis tempe. Rata-rata berat badan tikus sebelum intervensi berkisar antara 194,1 g - 200,6 g, berdasarkan uji Kruskal Wallis tidak ada perbedaan yang bermakna berat badan tikus antar perlakuan sebelum intervensi $(\mathrm{p}=0,149)$, sedangkan setelah intervensi rata-rata berat badan tikus meningkat berkisar antara 214,3g-221,4g. Berdasarkan uji Kruskal Walis tidak terdapat perbedaan peningkatan berat badan yang bermakna antar kelompok setelah intervensi $(\mathrm{p}=0,608)$.

Kadar MDA dan SOD sebelum aktivitas fisik dan perlakuan. Pemeriksaan kadar MDA dan SOD dilakukan setelah aklimatisasi pada hari ke 4 untuk standarisasi kadar normal MDA dan SOD ketika tikus belum mengalami stres oksidatif atau masih dalam kondisi sehat.

Tabel 1. Rata-rata berat badan tikus (g)

\begin{tabular}{|c|c|c|c|c|c|c|}
\hline \multirow{2}{*}{$\begin{array}{l}\text { Berat badan } \\
\quad(\mathrm{g})\end{array}$} & \multicolumn{5}{|c|}{ Kelompok } & \multirow{2}{*}{$\mathrm{p}^{*}$} \\
\hline & K1 & $\mathrm{K} 2$ & P1 & P2 & P3 & \\
\hline $\begin{array}{l}\text { Awal } \\
\text { penelitian }\end{array}$ & $199,6 \pm 2,70$ & $196,1 \pm 3,25$ & $194,1 \pm 4,16$ & $198,0 \pm 7,61$ & $200,6 \pm 2,60$ & 0,149 \\
\hline $\begin{array}{l}\text { Akhir } \\
\text { penelitian }\end{array}$ & $220,2 \pm 1,92$ & $217,3 \pm 4,32$ & $214.3 \pm 4,67$ & $218,5 \pm 7,94$ & $221,4 \pm 2,70$ & 0,218 \\
\hline$\Delta$ & 20,6 & 21,1 & 20,1 & 20,0 & 20,8 & 0,608 \\
\hline
\end{tabular}


Harun dkk.

Tabel 2. Kadar Malondialdehid (MDA) dan Superoxide Dismutase (SOD) tikus sebelum aktivitas dan perlakuan

\begin{tabular}{lcccc}
\hline \multicolumn{1}{c}{ Perlakuan } & $\begin{array}{c}\text { Kadar MDA }(\mathrm{nmol} / \mathrm{ml}) \\
\text { Rata-rata } \pm \text { SD }\end{array}$ & $\mathrm{p}^{*}$ & $\begin{array}{c}\text { Kadar SOD }(\mathrm{U} / \mathrm{ml}) \\
\text { Rata-rata } \pm \text { SD }\end{array}$ & $\mathrm{p}^{*}$ \\
\hline K1 & $1,52 \pm 0,32$ & 0,342 & $81,45 \pm 5,53$ & 0,593 \\
K2 & $1,30 \pm 0,14$ & & $77,94 \pm 6,47$ & \\
P1 & $1,49 \pm 0,26$ & & $81,45 \pm 4,15$ & \\
P2 & $1,52 \pm 0,24$ & & $77,44 \pm 5,76$ & \\
P3 & $1,54 \pm 0,17$ & & $80,45 \pm 7,80$ & \\
\hline *one Way Anova & & &
\end{tabular}

Tabel 2 menunjukkan bahwa nilai rata-rata kadar MDA pada tikus sebelum dilakukan induksi aktivitas fisik tinggi dan perlakuan pemberian tempe berkisar antara $1,30 \mathrm{nmol} / \mathrm{ml}$ sampai $1,54 \mathrm{nmol} / \mathrm{ml}$. Berdasarkan uji One Way Anova menunjukkan tidak terdapat perbedaan yang bermakna kadar MDA antar perlakuan $(\mathrm{p}=0,342)$ sedangkan rata-rata kadar SOD berkisar antara $77,44 \mathrm{U} / \mathrm{ml}$ sampai $81,45 \mathrm{U} / \mathrm{ml}$, berdasarkan uji One Way Anova menunjukkan tidak ada perbedaan kadar SOD yang bermakna antar perlakuan $(\mathrm{p}=0,593)$.

\section{Pengaruh pemberian tempe terhadap kadar MDA dan aktivitas enzim SOD}

Tabel 3 menunjukkan bahwa kadar MDA plasma tertinggi terdapat pada perlakuan K1 sebesar $(7,16 \pm 0,60 \mathrm{nmol} / \mathrm{ml})$, ini berarti bahwa tikus sudah berada pada kondisi stres oksidatif. Terjadi peningkatan kadar MDA plasma dikarenakan tingginya aktivitas yang dilakukan setiap hari selama 30 hari, mengakibatkan terjadinya ketidakseimbangan antara jumlah antioksidan dan radikal bebas di dalam tubuh. Jumlah antioksidan akan sangat dipengaruhi oleh jumlah radikal bebas yang terbentuk di dalam tubuh selama aktivitas fisik tinggi (Baghaiee et al. 2016). Hasil penelitian ini sejalan dengan penelitian sebelumnya bahwa pada kelompok dengan aktivitas fisik yang berlebih memiliki rata-rata kadar MDA paling tinggi (Arsana 2014). Penelitian Rosidi juga menyatakan bahwa terjadi peningkatan kadar MDA setelah aktivitas fisik (Rosidi 2013).

Pemberian perlakuan berupa tempe pada penelitian ini bertujuan untuk menurunkan kadar MDA plasma akibat stres oksidatif. Berdasarkan uji one way anova, perlakuan pemberian tempe dengan dosis $0,75 \mathrm{~g}, 1,5 \mathrm{~g}$ dan $3 \mathrm{~g}$ mengakibatkan penurunan kadar MDA plasma secara signifikan $(\mathrm{p}<0,05)$. Pemberian tempe dengan dosis $1,5 \mathrm{~g}$ dan $3 \mathrm{~g} / 200 \mathrm{~g}$ bb merupakan dosis optimal karena mempunyai efek yang sama dalam menurunkan kadar MDA plasma.

Tempe mengandung senyawa isoflavon dalam bentuk deidzein dan genistein yang berperan sebagai antioksidan sehingga dapat menetralisir adanya radikal bebas yang dapat mencegah peroksidasi lipid sehingga MDA sebagai hasil akhir dari peroksidasi lipid juga menurun (Suarsana et al. 2014). Hasil penelitian ini sejalan dengan penelitian Yoon dan Park (2014) bahwa perlakuan dengan exercise yang dilakukan lima hari dalam seminggu selama lima bulan dengan pemberian isoflavon dengan dosis 2,5 $\mathrm{mg} / \mathrm{kg}$ dapat menurunkan MDA TBARS. Sejalan dengan penelitian Feng dan Zang (2016), menyatakan bahwa terdapat penurunan yang signifikan terhadap kadar MDA yang diberikan isoflavon dosis tinggi dibandingkan kelompok kontrol setelah aktivitas fisik maksimal pada tikus.

Aktivitas enzim SOD plasma setelah pemberian intervensi tempe menunjukkan bahwa setelah aktivitas tinggi pada kelompok K1 mempunyai kadar aktivitas enzim SOD paling rendah sebesar 18,57 U/ml, hal ini disebabkan karena tingginya kadar radikal bebas dalam tubuh tikus selama aktivitas fisik tinggi sehingga antioksidan endogen dalam tubuh tidak mampu menetralisir radikal bebas (Astuti 2008).

Kelompok perlakuan P3 memiliki aktivitas enzim SOD paling tinggi sebesar 70,35 U/ $\mathrm{ml}$ dan hampir mencapai keadaan normal, terjadi peningkatan aktivitas enzim SOD bersamaan dengan penurunan kadar TBARS karena bahan

Tabel 3. Rata-rata kadar malondialdehyde (MDA) dan Aktivitas Enzim SOD tikus setelah intervensi

\begin{tabular}{ccccc}
\hline Perlakuan & $\begin{array}{c}\text { Kadar MDA }(\mathrm{nmol} / \mathrm{ml}) \\
\text { Rata-rata } \pm \text { SD }\end{array}$ & $\mathrm{p}^{*}$ & $\begin{array}{c}\text { Kadar SOD }(\mathrm{U} / \mathrm{ml}) \\
\text { Rata-rata } \pm \text { SD }\end{array}$ & $\mathrm{p}^{*}$ \\
\hline K1 & $7,16 \pm 0,60^{\mathrm{a}}$ & 0,000 & $18,57 \pm 4,82^{\mathrm{a}}$ & 0,000 \\
K2 & $1,69 \pm 0,22^{\mathrm{b}}$ & & $72,91 \pm 3,97^{\mathrm{b}}$ & \\
P1 & $3,85 \pm 0,38^{\mathrm{c}}$ & & $34,52 \pm 7,71^{\mathrm{c}}$ & \\
P2 & $2,42 \pm 0,32^{\mathrm{d}}$ & & $61,60 \pm 5,50^{\mathrm{d}}$ & \\
P3 & $2,27 \pm 0,37^{\mathrm{d}}$ & & $70,35 \pm 4,82^{\mathrm{b}}$ & \\
\hline *One Way Anova; a, b,c Post hoc LSD berbeda signifikan & &
\end{tabular}


makanan pada tempe merupakan hasil fermentasi dari kedelai yang mempunyai komponen zat bioaktif isoflavon (deidzein dan genistein) yang bertindak sebagai antioksidan eksogen (Haron et al. 2009; Yoon \& Park 2014).

Berdasarkan uji one way anova terdapat perbedaan aktivitas enzim SOD secara bermakna $(\mathrm{p}<0,05)$. Pemberian tempe dengan dosis $3 \mathrm{~g} / 200 \mathrm{~g}$ bb merupakan dosis efektif meningkatkan kadar aktivitas enzim SOD plasma dimana rata-rata pada kelompok P3 lebih tinggi dari semua kelompok perlakuan. Hasil penelitian ini sejalan dengan penelitian Astuti (2008), bahwa pemberian tepung kedelai yang kaya isoflavon dengan dosis $1,5 \mathrm{mg} /$ ekor/hari dapat menghambat pembentukan peroksidasi lipid dan mempertahankan kadar SOD tetap tinggi. Penelitian Utari (2011) juga menyatakan bahwa konsumsi tempe dapat meningkatkan aktivitas enzim SOD dalam darah sebesar $56,9 \%$.

Genistein merupakan antioksidan yang berperan sebagai pelindung dalam mengurangi pembentukan radikal bebas dan oksigen reaktif sehingga diperlukan untuk melindungi sel untuk melawan adanya lipid peroksidasi. Selain itu juga isoflavon genestein mampu meningkatkan ekspresi MnSOD melalui interaksi dengan reseptor estrogen dalam sel (Jiang et al. 2008; Yoon \& Park 2014).

SOD akan bekerja secara maksimal tergantung pada logam $\mathrm{Cu} / \mathrm{Zn}$, Fe dan $\mathrm{Mn}$ yang dapat melindungi sel-sel dan jaringan dari serangan radikal bebas. Tempe mempunyai mineral-mineral yang lengkap diantaranya $\mathrm{Cu}$, Fe dan $\mathrm{Zn}$ dimana mineral tersebut berperan sangat penting sebagai kofaktor enzim-enzim antioksidan sehingga mampu menunjang aktivitas enzim SOD di dalam tubuh. Mineral yang terkandung dalam tempe mudah diserap oleh usus halus (Astuti 2008; Lobo et al. 2010; Yoon \& Park 2014).

Pada kelompok K2 yang diberi suplemen menunjukkan peningkatan kadar SOD paling tinggi diantara semua kelompok perlakuan, namun mengonsumsi suplemen multivitamin sintetik tentunya berbahaya dan dapat merugikan, seperti ketergantungan, harga yang mahal dan daya larutnya yang sangat rendah (Sayuti \& Yenrina 2015).

\section{KESIMPULAN}

Terjadi penurunan kadar MDA dan peningkatan aktivitas enzim SOD pada tikus stres oksidatif pada perlakuan pemberian tempe dosis $0,75 \mathrm{~g} / 200 \mathrm{~g} \mathrm{bb}, 1,5 \mathrm{~g} / 200 \mathrm{~g}$ bb, dan $3 \mathrm{~g} / 200 \mathrm{~g} \mathrm{bb}$ secara signifikan. Pemberian tempe $3 \mathrm{~g} / 200 \mathrm{~g} b \mathrm{~b}$ merupakan dosis efektif terhadap penurunan kadar MDA dan peningkatan aktivitas enzim SOD.

Penelitian selanjutnya perlu dilakukan pengujian kandungan senyawa aktif isoflavon dan zat gizi secara keseluruhan pada tempe yang digunakan sebagai intervensi khususnya yang berkaitan dengan antioksidan.

\section{DAFTAR PUSTAKA}

Arsana NI. 2014. Ekstrak kulit buah manggis (garnicia mangostana L.) dan pelatihan fisik menurunkan stres oksidatif pada tikus wistar selama aktivitas fisik maksimal [Disertasi]. Denpasar: Universitas Udayana.

Astawan M, Wresdiyati T, Ichsan M. 2016. Karakteristik fisikokimia tepung tempe kecambah kedelai.J Gizi Pangan 11(1):35-42.

Astuti M, Meliala A, Dalais FS, Wahlqvist A. 2000. Tempe, a nutritious and healthy food from Indonesia. Asia Pac J Clin Nutr 9(4):322-325. doi: 10.1046/j.14406047.2000.00176.x.

Astuti S. 2008. Isoflavon kedelai dan potensinya sebagai penangkap radikal bebas. Jurnal teknologi industri dan hasil pertanian Universitas Lampung 13(2):126-136.

Baghaiee B, Aliparasti ML, Almasi S, Siahkuihan M, Baradaran B. 2016. Antioxidant expression response to free radicals in active men and women fallowing to a session incremental exercise; Numerical relationship between antioxidants and free radicals. Asian J Sport Med 7(2).doi: 10.5812/asjsm.29901.

Bhagwat S, Haytowitz DB, Holden JM . 2008. USDA Database for the isoflavone content of selected Foods, U.S. department of argiculture.doi: http://www.ars.usda.gov/ SP2UserFiles/Place/12354500/Data/isoflav/Isoflav R2. pdf.

Desminarti S, Anwarar F. 2012. Efek bubuk tempe instan terhadap kadar malonaldehida ( MDA ) Serum tikus hiperglikemik. Jurnal Kedokteran Hewan 6(2):72-74.

Feng J, Zhang T. 2016. Remission effect of soy isoflavone on sport fatigue and its. JFST 8(3):31-37.

Haron H, Ismail A, Azlan A, Shahar S, Peng LS 2009. Daidzein and genestein contents in tempeh and selected soy products. J Food Chemistry 115(4):1350-1356. doi: 10.1016/j.foodchem.2009.01.053.

Jiang ZY, Jiang SQ, Lin YC, Ma XY, Xi PB, Cao T, Wang XQ. 2008 Effect of genistein on antioxidative defence system and membrane fluidity in chick skeletal muscle cells. Asian-Aust Animal Science 21(8):1220-1225.

Kiyatno. 2009. Antioksidan vitamin dan kerusakan otot pada aktivitas fisik. M Med Indones 43(6):277-281. 
Harun dkk.

Lobo V, Patil A, Phatak A, Chandra N.2010. Free radicals, antioxidants and functional foods: Impact on human health. Pharmacognosy reviews 4(8):1181-26. doi: 10.4103/09737847.70902.

Moselhy HF, Reid RG, Yousef S, Boyle Sp.2013. A specific, accurate, and sensitive measure of total plasma malondialdehyde by HPLC. Journal of lipid research 54(3):852-858. doi: 10.1194/jlr.D032698.

Pingitore A, Lima GPP, Mastorci F, Qinones A, Iervasi G, Vasalle C.2015. Exercise and oxidative stress: Potential effects of antioxidant dietary strategies in sports. J. Nutr 31(7-8):916-922. doi: 10.1016/j. nut.2015.02.005.

Powers SK, Jackson MJ. 2010. Exercise induced oxidative stress: cellular mechanisms and impact on muscle force production. NIH Public Access 88(4):1243-1276. doi: 10.1152/physrev.00031.2007.ExerciseInduced.

Rosidi A. 2013. Pengaruh pemberian ekstrak temulawak (curcuma xanthorrhiza roxb) terhadap stres oksidatif dan kesegaran jasmani atlet.[Disertasi].Bogor: Institut Pertanian Bogor.

Sayuti K, Yenrina R. 2015. Antioksidan alami dan sintetik. Padang: Andalas University Press.
Suarsana IN Astawa IN, Kardena IM. 2014. Role of isoflavones on lipid peroxidation, superoxide dismutase in lymphocytes under oxidative stress conditions Journal of Biology, Agriculture and Healthcare 4(12):1-8.

Turner JE, Hodges NJ, Bosch JA, Aldred S. 2011. Prolonged Depletion of Antioxidant Capacity after Ultra endurance Exercise. Med. Sei. Sports Exerc 43(9):1770-1776. doi: 10.1249/MSS.ObO.

Utari DM. (2011) Efek intervensi tempe terhadap profil lipid,superoksida dismutase, LDL teroksidasi dan malondialdehyde pada wanita menopause.[Thesis]. Bogor: Institut Pertanian Bogor.

Utari DM, Riyadi H. 2010. Effects of soybean processing becoming tempeh and the cooking of tempeh on isoflavones level. PGM 33(2):148-153.

Williams MH. 2004. Dietary supplements and sports performance introduction and vitamins. JISSN 1(2):1-6. doi: 10.1186/15502783-1-2-1.

Yavari A, Javadi M, Mirmiran P, Bahadoran Z. 2015. Exercise induced oxidative stress and dietary antioxidants. AJSM 6(1):1-7. doi:10.5812/asjsm.24898.

Yoon GA, Park S. 2014. Antioxidant action of soy isoflavones on oxidative stress and antioxidant enzyme activities in exercised rats. Nutr Res Pract 8(6):618-624. doi: 10.4162/nrp.2014.8.6.618. 